\title{
MANAJEMEN PERPUSTAKAAN DALAM PENINGKATAN KUALITAS LAYANAN DAN MINAT BACA
}

\section{LIBRARY MANAGEMENT ON IMPROVING THE QUALITY OF SERVICE AND READING INTEREST}

\author{
Naimah. Barowi, Moh Nasuka \\ Universitas Islam Nahdlatul Ulama Jepara \\ e-mail: naimahelm@gmail.com \\ e-mail: a.barowi@gmail.com \\ email:mohnasuka@gmail.com
}

\begin{abstract}
This research aimed to find out about library management which included planning, organizing, staffing, directing, and controlling for the improvement of service and students' reading interest at SMPN 3 Salatiga. This research used qualitative approach. Type of this research was descriptive. The research was done in Adyama Pustaka Library of SMPN 3 Salatiga. Data was collected by observation, interview, and documentation. From the result of the research, it can be concluded that: 1) planning of library work program at SMPN 3 Salatiga is in accordance with the planning of library program which are purpose, policy, strategy, and program. All of formulated work program has described about the purpose, policy, strategy, and upcoming program to achieve the desire result. 2) Implementation of library work program at SMPN 3 Salatiga in improving the quality of service and reading interest includes; implementation of differentiation program, processing literature, implementation of service program, implementation of data analysis program, implementation of students' activity program, implementation of promotion program, and implementation of inventory taking. The implementation of library work program at SMPN 3 Salatiga has been running well. Then, added by establishment with intern and extern part. 3) Evaluation of planning and implementation of library work program is as a basis for determining policies in the following year.
\end{abstract}

Keywords: Service Quality; Library Management; Reading Interest

\begin{abstract}
Abstrak
Penelitian ini bertujuan untuk mengetahui tentang manajemen perpustakaan yang meliputi perencanaan, organisasi, kepegawaian, pengarahan, dan pengawasan, serta untuk peningkatan layanan dan minat baca siswa SMP 3 Salatiga. Penelitian ini menggunakan pendekatan kualitatif. Jenis penelitian ini adalah deskriptif. Penelitian dilaksanakan di perpustakaan Adyama Pustaka SMPN 3 Salatiga. Data dikumpulkan melalui observasi, wawancara, dan dokumentasi data. Dari hasil penelitian disimpulkan bahwa: 1) perencanaan program kerja perpustakaan SMPN 3 Salatiga sudah sesuai dengan perencanaan program perpustakaan yang terdiri dari tujuan, kebijakan, strategi, dan program. Semua program kerja yang telah dirumuskan sudah menggambarkan aspek tujuan, kebijakan, strategi, dan program yang akan dilaksanakan untuk mencapai hasil yang dikehendaki. 2) Pelaksanaan program kerja perpustakaan di SMPN3 Salatiga dalam meningkatkan kualitas
\end{abstract}


layanan dan minat baca meliputi; pelaksanaan program pengadaan, pengolahan bahan pustaka, pelaksanaan program layanan, pelaksanaan program pengolahan data, pelaksanaan program kegiatan siswa, pelaksanaan program promosi, dan pelaksanaan stock opname. Pelaksanaan program kerja perpustakaan SMPN 3 Salatiga sudah berjalan dengan baik. Ditambah lagi dengan upaya perpustakaan SMPN3 Salatiga untuk menjalin kerjasama dengan pihak intern dan ekstern. 3) Evaluasi terhadap perencanaan dan pelaksanaan program kerja perpustakaan sebagai pijakan untuk menentukan kebijakan-kebijakan manajemen perpustakaan pada tahun berikutnya.

Kata Kunci: Kualitas Layanan; Manajemen Perpustakaan; Minat Baca

\section{PENDAHULUAN}

Dalam suatu instansi, institusi, ataupun universitas keberadaan perpustakaan merupakan suatu keharusan. Tidak hanya dijadikan tempat untuk menyimpan buku, perpustakaan juga digunakan sebagai tempat untuk mencari informasi baik yang bersifat ilmiah, sejarah, maupun informasi populer (Saleh \& Komalasari, 2010:1). Dalam pelaksanaannya di sekolah, perpustakaan telah diatur secara sistematis dalam suatu ruang sehingga dapat membantu para siswa dan para guru dalam proses pembelajaran (Prastowo, 2013:76).

Tujuan diadakannya perpustakaan berdasarkan pasal 4 UU Nomor 43 Tahun 2007 tentang perpustakaan adalah memberikan layanan kepada pengguna perpustakaan, meningkatkan kegemaran membaca, serta memperluas wawasan dan pengetahuan dalam rangka mencerdaskan kehidupan bangsa. Pengadaan perpustakaan juga dipertegas dalam UU Sistem Pendidikan Nasional Nomor 2 Tahun 1989 yang menyatakan bahwa setiap sekolah harus menyediakan sumber belajar berupa perpustakaan.

Perpustakaan merupakan salah satu sumber informasi yang diselenggarakan dan dikelola sepenuhnya oleh suatu lembaga pendidikan atau instansi dengan tujuan utama untuk mendukung terlaksananya serta tercapainya tujuan sekolah khususnya dan tujuan pendidikan pada umumnya (Hermawan et al., 2020:114). Jadi, dalam suatu perpustakaan terdapat berabagai sumber informasi yang digunakan untuk menunjang proses pembelajaran di sekolah. Mulai dari buku ajar, koran, majalah, buku-buku latihan, maupun media digital yang bisa dijadikan sebagai sumber informasi.

Dalam suatu perpustakaan biasanya ada seorang pustakawan. Keberadaan pustakawan ini sebagai perwujudan dari pelaksanaan fungsi terpenting perpustakaan, yaitu menarik lebih banyak pengguna perpustakaan, menolong pengguna mencari dan mendayagunakan semua informasi serta fasilitas yang ada di perpustakaan, menginformasikan informasi dan fasilitas baru, membangkitkan minat baca dan belajar, serta menjangkau semua elemen masyarakat sesuai dengan objek masingmasing suatu perpustakaan (Ibrahim, 2014:129).

Berperannya perpustakaan sebagai pusat sarana belajar seringkali melibatkan penggunaan koleksi sebagai sumber 
belajar dan ruangan perpustakaan sebagai sarana kegiatan belajar. Sejalan dengan ilmu pengetahuan dan teknologi serta berlimpahnya informasi, kebutuhan akan sumber-sumber informasi mengalami perubahan dan perkembangan (Sudarsana \& Bastiono, 2010:33). Pelayanan adalah proses atau kegiatan yang berkaitan dengan pendayagunaan koleksi dan fasilitas yang tersedia di perpustakaan. Pelayanan merupakan proses kesinambungan suatu kegiatan yang terus menerus dalam upaya mempertemukan koleksi dan fasilitas dengan pemakai. Pelayanan perpustakaan tidak terbatas pada proses peminjaman bahan pustaka saja, tetapi juga menyediakan lingkungan belajar yang menyenangkan ditunjang oleh kelengkapan koleksi yang relevan dan petugas perpustakaan yang kompeten.

Salah satu peran perpustakaan sebagai sumber atau penyedia informasi adalah meningkatkan minat baca. Dengan ketersediaan koleksi di perpustakaan dapat dimanfaatkan untuk meningkatkan minat baca. Pembudayaan kegemaran membaca diatur dalam UU No. 43 Tahun 2007 Bab XIII pasal 48 ayat 3 yang menyatakan bahwa pembudayaan kegemaran membaca dilakukan dengan mengembangkan dan memanfaatkan perpustakaan sebagai proses pembelajaran (Hermawan et al., 2020:116).

Dikarenakan pentingnya perpustakaan tersebut, suatu sekolah atau instansi harus membuat sebuah manajemen yang baik dan teratur agar perpustakaan dapat benar-benar berjalan sebagaimana mestinya. Namun, pada prakteknya di lapangan manajemen perpustakaan belum berjalan dengan baik. Manajemen perpustakaan teridiri dari dua kata yaitu manajemen dan perpustakaan.
Manajemen adalah proses yang didalamnya terdapat perencanaan, pengorganisasian, pelaksanaan, serta pengawasan dalam rangka mencapai tujuan suatu organisasi (Luthfiyah, 2015:191). Sedangkan perpustakaan adalah suatu unit kerja dari suatu badan atau lembaga tertentu yang mengelola bahan-bahan pustaka baik berupa bukubuku maupun non buku yang diatur secara sistematis menurut aturan tertentu sehingga dapat digunakan sebagai sumber informasi oleh setiap pemakainya (Bafadal, 2011:3).

Jadi, manajemen perpustakaan adalah upaya dari sebuah organisasi sekolah atau instansi perpustakaan untuk mencapai tujuan yang tertuang dalam visi dan misi organisasi melalui sebuah proses yang dilakukan secara bersama atau berkelompok (Ibrahim, 2014:131). Dengan kata lain manajemen perpustakaan merupakan sebuah proses untuk mengoptimalkan kontribusi sumber daya manusia, material, serta anggaran dalam rangka mencapai tujuan perpustakaan (Rokan, 2017:90).

Suhaemin dan Arikunto (2013) memaparkan bahwa tahapan dalam manajemen perpustakaan terdiri dari perencanaan pengadaan buku per tahun, pengorganisasian, pelaksanaan (pengadaan, pengolahan, pelayanan, dan pembinaan), serta pengawasan yang dilakukan oleh kepala sekolah. Hermawan, Hidayat, Fajari (2020) menjelaskan bahwa manajemen perpustakaan dalam rangka meningkatkan minat baca dapat dilakukan melalui beberapa tahapan, yaitu: 1) perencanaan perpustakaan dapat dilakukan melalui musyawarah, 2) pengorganisasian dilakukan dengan pemilihan dan 
disepakati bersama, 3) pelaksanaan dilaksanakan berdasarkan perencanaan dan diawasi oleh pengawas yang telah disepakati.

Tidak seperti penelitian sebelumnya yang berfokus pada manajemen perpustakaan dan juga minat baca, penelitian kali ini berfokus kepada manajemen perpustkaan dalam meningkatkan kualitas pelayanan dan juga minat baca. Jadi penelitian ini bertujuan untuk mengetahui dan mendeskripsikan kualitas perencanaan, pelaksanaan, dan evaluasi dalam meningkatkan kualitas layanan dan minat baca siswa Sekolah Menengah Tingkat Pertama 3 Salatiga.

\section{METODE PENELITIAN}

Penelitian ini merupakan penelitian kualitatif, yaitu suatu prosedur penelitian yang menggunakan data deskriptif berupa kata-kata tertulis maupun lisan dari orang-orang dan pelaku yang bisa diamati (Sudjana \& Ibrahim, 2012:64). Penelitian ini dilakukan di SMP N 3 Salatiga yang berlokasi di Jl. Stadion Mangunsari Sidomukti, Kota Salatiga, Jawa Tengah. Penelitian ini dilaksanakan selama 1 bulan untuk mengetahui secara detail bagaimana manajemen perpustakaan di SMP N 3 Salatiga.

Pengambilan data dalam penelitian ini dengan cara snowball sampling, yaitu informan kunci menunjuk orang-orang yang mengetahui masalah yang diteliti untuk melengkapi keterangannya dan orang-orang yang ditunjuk dan menunjuk orang lainnya apabila keterangan kurang memadai begitu seterusnya. Kemudian untuk pengumpulan datanya melalui observasi partisipan pasif, wawancara (interview), dan dokumentasi. Setelah memperoleh semua data yang dibutuhkan, data kemudian dianalisis menggunakan analisis data kualitatif.

\section{HASIL DAN PEMBAHASAN}

Untuk memberikan pelayanan kepada pemustaka dan sebagai upaya untuk meningkatkan minat baca siswa, perpustakaan SMP N 3 Salatiga mengadakan berbagai upaya dalam hal manajemen pengelolaan perpustakaan. Sebgaimana hasil wawancara dengan Ibu Retno Setyowati, S.Pd selaku kepala perpustakaan menyatakan bahwa manajemen perpustakaan di SMP N 3 Salatiga terdiri dari perencanaan program kerja, pelaksanaan, dan evaluasi.

\section{Perencanaan Program Kerja}

Perencanaan adalah suatu pemilihan yang berhubungan dengan kenyataan-kenyataan serta membuat dan menggunakan anggapan di masa yang akan datang dalam menggambarkan dan merumuskan kegiatan yang diusulkan dengan penuh keyakinan untuk tercapainya hasil yang diinginkan (Sumiati, 2011:122). Perencanaan program kerja perpustakaan yang dilakukan di SMP N 3 Salatiga meliputi, pengadaan, pengelolaan bahan pustaka, layanan, pengolahan data, kegiatan siswa, promosi, dan stock opname.

Berdasarkan keterangan Ibu Retno Setyowati, S.Pd. menyatakan bahwa pengadaan dilaksanakan secara rutin setiap bulan dan hal ini disesuaikan dengan kurikulum yang berlaku di sekolah. Selain itu, pengadaan juga memperhatikan hal lain seperti kebutuhan sekolah maupun kebutuhan persiapanpersiapan lomba yang hendak dilaksanakan baik oleh siswa maupun sekolah. 
Program pengadaan dimulai dari inventarisasi yang disesuaikan dengan kebutuhan sekolah terkait dengan kurikulum yang dilaksanakan. Pengadaan itu disesuaikan dengan kebutuhan siswa sebagai upaya menambah sejumlah buku pelajaran. Kegiatan yang dilaksanakan pada program ini adalah dengan melakukan pencatatan bahan pustaka baru ke buku induk serta berlangganan terbitan baru berupa surat kabar, seperti suara merdeka, jawa pos, dan terbitan lainnya yang terdiri dari 4 surat kabar dan 16 majalah terbitan berseri.

Keberadaan perpustakaan sebagai sarana untuk mendukung pembelajaran di dalam kelas. Selama ini buku-buku pelajaran yang dimiliki oleh siswa dirasakan belum cukup mendukung proses kegiatan belajar mengajar di kelas. Terlebih kurikulum yang diterapkan di SMP N 3 Salatiga adalah kurikulum 2013 yang banyak menggunakan berbagai sumber. Keberadaan perpustakaan sekolah adalah menyediakan berbagai buku yang tidak dimiliki oleh siswa, sehingga keberadaan tersebut sangat strategis. Pengadaan buku secara rutin ini juga sebagai bentuk dukungan kepada siswa agar tidak mengeluarkan biaya tambahan untuk membeli buku tambahan.

Lebih lanjut kegiatan yang dilaksanakan dalam pngelolaan bahan pustaka ini adalah memberi stempel, memberi nomor induk, memberi sampul buku yang rusak maupun buku baru serta membagikan kepada seluruh siswa kelas VII, VIII dan IX. Pemberian stempel dengan tujuan untuk membedakan buku pribadi dan buku inventaris perpustakaan.

Pengolahan bahan pustaka ini merupakan tugas staf perpustakaan yang dikendalikan langsung oleh kepala perpustakaan dengan tugas dan tanggungjawab antara lain melakukan katalogisasi dan klasifikasi yang bertujuan untuk memudahkan penelusuran koleksi buku di perpustakaan. Selanjutnya melakukan entry data terhadap buku baru ke bank data perpustakaan. Saat ini perpustakaan telah memiliki sistem secara online dan berbasis teknologi informasi, sehingga entry data buku baru dan lama ataupun proses peminjaman buku baik oleh guru maupun siswa dapat dimasukkan secara otomatis. Langkah ini dilakukan sebagai upaya untuk memudahkan kinerja pustakawan dalam mengelola perpustakaan. Tugas staf perpustakaan selanjutnya adalah melakukan pelabelan dan display buku.

Untuk menunjang kinerja perpustakaan, maka kepala perpustakaan dibantu oleh 5 staf dengan tugas dan kewajiban yang telah ditetapkan. Kegiatan yang dilaksanakan terkait dengan layanan adalah sebagai upaya untuk meningkatkan minat baca bagi guru dan siswa serta dalam rangka memberikan user satisfaction kepada pemustaka. Kegiatan layanan bimbingan membaca dilaksakan setiap saat yang berfungsi sebagai alat untuk membantu pemustaka agar dapat menggunakan fasilitas perpustakaan secara maksimal dan memperoleh informasi tentang kemampuan minat baca siswa. Kepala perpustakaan juga melihat serta melakukan pengawasan kepada seluruh siswa dan pada akhirnya membentuk kelompok siswa pecinta membaca dengan program khusus yang akan diproyeksikan mengikuti perlombaan-perlombaan.

Pengolahan data merupakan kegiatan mengolah berbagai informasi dan membuat laporan pada setiap tahunnya. 
Pengolahan data meliputi laporan perpustakaan setiap tahun dan statistik perpustakaan. Kegiatan ini melibatkan seluruh staff yang ada dan bentuk laporan disajikan serta dilaporkan kepada penanggungjawab perpustakaan yaitu kepala sekolah. Pengolahan data mempunyai tujuan untuk melakukan evaluasi secara rutin sekaligus untuk mengetahui sejauh mana perkembangan minat baca siswa. Kegiatan ini dalam bentuk laporan secara bulanan kepada penanggung jawab perpustakaan sekaligus menyampaikian beberapa program yang bersifat mendadak.

Kegiatan siswa terkait dengan perpustakaan dibagi ke dalam tiga kelompok yaitu kelas VII sebagai kelompok pemula dan kelas VIII dan IX kelompok tindak lanjut. Kegiatan siswa terkait dengan perpustakaan adalah memasukkan program perpustakaan sedini mungkin semenjak siswa baru mulai masuk sekolah dalam program MOS. Antusias siswa untuk membaca di perpustakaan mulai meningkat ketika perpustakaan dimasukkan ke dalam program ekstrakurikuler, sehingga membaca di perpustakaan berkembang menjadi suatu kewajiban bagi seluruh siswa.

Kegiatan promosi dilaksanakan pada awal tahun ajaran baru atau sesuai waktu yang dibutuhkan. Siswa baru yang masuk ke kelas VII mendapat bimbingan membaca pada saat dan di sela-sela kegiatan MOS. Tujuan utama dari kegiatan promosi ini adalah memperkenalkan perpustakaan sekolah kepada siswa baru. Kegiatan ini rutin dilaksanakan setiap tahun ajaran baru dan sambutan siswa selama ini cukup bagus. Kegiatan promosi selama ini berjalan cukup baik dari waktu ke waktu dan tidak ada kendala yang berarti.

Program stock opname perpustakaan bertujuan untuk mengecek koleksi buku dan harta yang dimiliki, mengetahui kondisi koleksi maupun semua harta kekayaan yang dimiliki oleh perpustakaan untuk diambil suatu kebijakan di akhir tahun ajaran, biasanya dilakukan pada bulan Juni sampai dengan Juli.

Tabel 01 Program Kerja Perpustakaan SMP N 3 Salatiga

\begin{tabular}{|c|c|c|c|}
\hline Sasaran & Kegiatan & Tujuan & Waktu \\
\hline \multicolumn{4}{|l|}{ Pengadaan } \\
\hline $\begin{array}{l}\text { Persiapan dan } \\
\text { seleksi }\end{array}$ & $\begin{array}{l}\text { Melakukan survey kebutuhan } \\
\text { melalui alat seleksi pustaka dan } \\
\text { usulan pengadaan pustaka dari } \\
\text { pengguna }\end{array}$ & $\begin{array}{l}\text { Mendapatkan } \text { koleksi } \\
\text { yang aktual dan sesuai } \\
\text { dengan } \\
\text { pengguna }\end{array}$ & $\begin{array}{l}\text { Satu tahun } \\
\text { sekali }\end{array}$ \\
\hline $\begin{array}{l}\text { Pemesanan } \\
\text { atau } \\
\text { pembelian }\end{array}$ & $\begin{array}{l}\text { Melakukan pemesanan atau } \\
\text { pembelian langsung ke toko } \\
\text { buku }\end{array}$ & $\begin{array}{ll}\text { Penambahan } & \text { koleksi } \\
\text { sesuai } & \text { dengan } \\
\text { kebutuhan } & \\
\end{array}$ & $\begin{array}{l}\text { Satu tahun } \\
\text { sekali }\end{array}$ \\
\hline Inventarisasi & $\begin{array}{l}\text { Pencatatan bahan pustaka baru } \\
\text { ke Buku Penerimaan Barang } \\
\text { dan Buku Induk }\end{array}$ & \begin{tabular}{lr}
\multicolumn{2}{l}{ Pendataan koleksi yang } \\
telah diperoleh serta \\
untuk mengetahui \\
jumlah & keseluruhan \\
koleksi &
\end{tabular} & $\begin{array}{l}\text { Satu tahun } \\
\text { sekali }\end{array}$ \\
\hline Pemesanan & terbitan berseri & Memenuhi kebutuhan & Satu tahun \\
\hline
\end{tabular}




\begin{tabular}{|c|c|c|c|}
\hline $\begin{array}{l}\text { langganan } \\
\text { terbitan } \\
\text { berseri }\end{array}$ & berupa surat kabar dan majalah & $\begin{array}{l}\text { informasi aktual bagi } \\
\text { pembaca }\end{array}$ & sekali \\
\hline $\begin{array}{l}\text { Pengadaan } \\
\text { sarana dan } \\
\text { prasarana } \\
\text { fisik }\end{array}$ & $\begin{array}{l}\text { Membeli mebelair perpustakaan } \\
\text { berupa meja untuk taman baca, } \\
\text { galeri, koran diding, mading, } \\
\text { ruang audio visual, ruang } \\
\text { referensi, dan ATK }\end{array}$ & $\begin{array}{l}\text { Memenuhi kebutuhan } \\
\text { dan kenyamanan bagi } \\
\text { pengguna perpustakaan } \\
\text { setta memudahkan } \\
\text { kerja petugas } \\
\text { perpustakaan }\end{array}$ & $\begin{array}{l}\text { Satu tahun } \\
\text { sekali }\end{array}$ \\
\hline \multicolumn{4}{|c|}{ Pengolahan Bahan Pustaka } \\
\hline $\begin{array}{l}\text { Katalogisasi } \\
\text { dan klasifikasi }\end{array}$ & $\begin{array}{l}\begin{array}{l}\text { Pembuatan kartu katalog per } \\
\text { judul buku }\end{array} \text { dan } \\
\text { mengelompokkan buku sesuai } \\
\text { dengan sistem klasifikasi } \\
\text { Dewey Decimal Classification } \\
\text { (DDC) }\end{array}$ & $\begin{array}{l}\text { Memudahkan } \\
\text { penelusuran lokasi }\end{array}$ & $\begin{array}{l}\text { Setiap ada } \\
\text { buku baru }\end{array}$ \\
\hline $\begin{array}{l}\text { Input data dan } \\
\text { entry data } \\
\text { buku baru }\end{array}$ & $\begin{array}{l}\text { Memasukkan data semua buku } \\
\text { baru ke dalam sistem automasi } \\
\text { perpustakaan }\end{array}$ & $\begin{array}{lr}\text { Memudahkan } & \text { kinerja } \\
\text { perpustakaan } & \text { dan } \\
\text { penelusuran } & \text { koleksi } \\
\text { secara online } & \\
\end{array}$ & $\begin{array}{l}\text { Setiap ada } \\
\text { buku baru }\end{array}$ \\
\hline Pelabelan & $\begin{array}{l}\text { Penempelan barcode, label } \\
\text { buku, kantong buku, kartu buku, } \\
\text { lembar kembali }\end{array}$ & \begin{tabular}{lr}
\multicolumn{2}{l}{ Memudahkan } \\
penelusuran koleksi \\
dan memudahkan \\
petugas & dalam \\
melakukan & layanan \\
sirkulasi & \\
\end{tabular} & $\begin{array}{l}\text { Setiap ada } \\
\text { buku baru }\end{array}$ \\
\hline Display buku & $\begin{array}{l}\text { Meletakkan buku pada papan } \\
\text { display buku terbaru dan pada } \\
\text { rak sesuai dengan nomor } \\
\text { klasifikasi }\end{array}$ & $\begin{array}{l}\text { Memamerkan koleksi } \\
\text { buku terbaru dan } \\
\text { memudahkan } \\
\text { penelusuran koleksi }\end{array}$ & $\begin{array}{l}\text { Setiap ada } \\
\text { buku baru }\end{array}$ \\
\hline \multicolumn{4}{|l|}{ Layanan } \\
\hline Sirkulasi & $\begin{array}{l}\text { Melayani peminjaman dan } \\
\text { pengembalian buku }\end{array}$ & $\begin{array}{lr}\text { Membantu } & \text { kebutuhan } \\
\text { informasi } & \text { siswa dan } \\
\text { guru } & \text { dalam } \\
\text { meningkatkan } & \text { minat } \\
\text { baca siswa } & \\
\end{array}$ & Setiap hari \\
\hline Referensi & $\begin{array}{l}\text { Membantu pencarian koleksi } \\
\text { referensi/rujukan untuk siswa } \\
\text { dan guru }\end{array}$ & $\begin{array}{lr}\text { Membantu } & \text { layanan } \\
\text { penelusuran } & \text { informasi } \\
\text { primer } & \\
\end{array}$ & Setiap hari \\
\hline $\begin{array}{l}\text { Bimbingan } \\
\text { membaca }\end{array}$ & $\begin{array}{llr}\begin{array}{l}\text { Membimbing } \\
\text { pemanfaatan }\end{array} & \text { siswa } & \text { dalam } \\
\text { perpustakaan } & & \text { koleksi } \\
\end{array}$ & $\begin{array}{l}\text { Membantu proses } \\
\text { KBM di sekolah }\end{array}$ & Setiap hari \\
\hline Keanggotaan & $\begin{array}{l}\text { Memasukkan data anggota baru } \\
\text { secara automasi pembuatan } \\
\text { kartu perpustakaan }\end{array}$ & $\begin{array}{l}\text { Memudahkan layanan } \\
\text { sirkulasi dan statistik } \\
\text { anggota perpustakaan }\end{array}$ & Setiap hari \\
\hline $\begin{array}{l}\text { Penyediaan } \\
\text { buku } \\
\text { pelajaran }\end{array}$ & $\begin{array}{l}\text { Melayani kebutuhan buku-buku } \\
\text { pelajaran bagi siswa dan guru }\end{array}$ & $\begin{array}{l}\text { Membantu proses } \\
\text { KBM di kelas }\end{array}$ & $\begin{array}{l}\text { Awal tahun } \\
\text { ajaran baru, } \\
\text { Setiap hari }\end{array}$ \\
\hline
\end{tabular}




\begin{tabular}{|c|c|c|c|}
\hline $\begin{array}{l}\text { Layanan } \\
\text { orientasi yang } \\
\text { diberikan } \\
\text { kepada } \\
\text { pembaca }\end{array}$ & $\begin{array}{l}\text { Diberikan kepada siswa baru } \\
\text { berlangsung bersamaan dengan } \\
\text { kegiatan MOPDB, sedangkan } \\
\text { kelas VIII dan IX dilaksanakan } \\
\text { di sela-sela kegiatan tersebut }\end{array}$ & $\begin{array}{l}\text { Memanfaatkan waktu } \\
\text { luang bagi siswa }\end{array}$ & $\begin{array}{l}\text { Awal tahun } \\
\text { ajaran baru, } \\
\text { Setiap hari }\end{array}$ \\
\hline $\begin{array}{l}\text { Layanan } \\
\text { bimbingan } \\
\text { cara } \\
\text { mereview } \\
\text { buku }\end{array}$ & $\begin{array}{l}\text { Dilaksanakan secara klasikal } \\
\text { untuk kelas VIII dan IX } \\
\text { berkolaborasi dengan guru } \\
\text { bahasa Indonesia. Materi untuk } \\
\text { kelas VIII seputar cara } \\
\text { meresume buku dan kelas IX } \\
\text { materi menulis resensi }\end{array}$ & $\begin{array}{lr}\text { Sebagai } & \text { unsur } \\
\text { penunjang } & \text { mata } \\
\text { pelajaran } & \text { Bahasa } \\
\text { Indonesia } & \end{array}$ & $\begin{array}{l}\text { Sesuai } \\
\text { jadwal } \\
\text { KBM } \\
\text { Bahasa } \\
\text { Indonesia }\end{array}$ \\
\hline $\begin{array}{l}\text { Layanan } \\
\text { teknik } \\
\text { penelusuran } \\
\text { informasi }\end{array}$ & $\begin{array}{l}\text { Diberikan kepada pemustaka } \\
\text { yang datang ke perpustakaan } \\
\text { dan memerlukan cara } \\
\text { menelusuri informasi dengan } \\
\text { mudah dan cepat }\end{array}$ & Pembimbingan siswa & Setiap hari \\
\hline $\begin{array}{l}\text { Layanan } \\
\text { pendidikan } \\
\text { pemakai }\end{array}$ & $\begin{array}{l}\text { Membimbing siswa baru dalam } \\
\text { menggunakan seluruh fasilitas, } \\
\text { sumber informasi serta } \\
\text { mengetahui peraturan dan tata } \\
\text { tertib yang ada di perpustakaan }\end{array}$ & 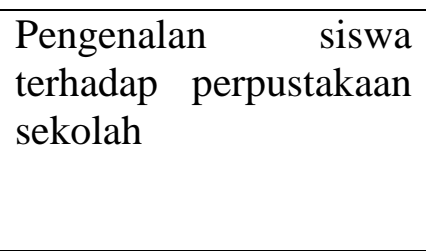 & Setiap hari \\
\hline $\begin{array}{l}\text { Bimbingan } \\
\text { mereview } \\
\text { buku }\end{array}$ & $\begin{array}{l}\text { Bimbingan kepada pemustaka } \\
\text { untuk mengkaji buku dengan } \\
\text { pemahaman yang lebih luas dan } \\
\text { mendalam }\end{array}$ & $\begin{array}{l}\text { Membantuk kebutuhan } \\
\text { informasi siswa dalam } \\
\text { mereview buku }\end{array}$ & $\begin{array}{l}\text { Setiap } \\
\text { dibutuhkan }\end{array}$ \\
\hline $\begin{array}{l}\text { Layanan } \\
\text { ruang baca }\end{array}$ & $\begin{array}{l}\text { Perpustakaan } \\
\text { ruang baca bagi pemyediakan } \\
\text { untuk membaca berbagai } \\
\text { macam koleksi yang ada di } \\
\text { perpustakaan }\end{array}$ & $\begin{array}{l}\text { Memberikan } \\
\text { kenyamanan, } \\
\text { meningkatkan } \\
\text { baca siswa }\end{array}$ & Setiap hari \\
\hline $\begin{array}{l}\text { Layanan } \\
\text { sirkulsi }\end{array}$ & $\begin{array}{l}\text { Layanan yang diberikan kepada } \\
\text { pemustaka anggota } \\
\text { perpustakaan untuk meminjam, } \\
\text { mengembalikan } \\
\text { memperpanjang atau } \\
\text { buku }\end{array}$ & $\begin{array}{l}\text { Membantu pemustaka } \\
\text { dalam peminjaman } \\
\text { buku di perpustakaan }\end{array}$ & Setiap hari \\
\hline $\begin{array}{l}\text { Layanan } \\
\text { akses internet }\end{array}$ & $\begin{array}{l}\text { Perpustakaan menyediakan } \\
\text { akses internet untuk melakukan } \\
\text { browsing informasi yang } \\
\text { bersifat ilmiah sebagai bahan } \\
\text { untuk KBM }\end{array}$ & $\begin{array}{l}\text { Membantu informasi } \\
\text { pemustaka dalam } \\
\text { kebutuhan internet }\end{array}$ & Setiap hari \\
\hline \multirow[t]{2}{*}{$\begin{array}{l}\text { Layanan } \\
\text { promosi }\end{array}$} & \multirow[t]{2}{*}{$\begin{array}{l}\text { Kegiatan ini dilakukan untuk } \\
\text { meningkatkan minat baca baik } \\
\text { bagi siswa maupun guru. }\end{array}$} & $\begin{array}{l}\text { Memberikan fasilitas } \\
\text { berupa bahan pustaka } \\
\text { sebagai rujukan kegiatan } \\
\text { MGMP }\end{array}$ & $\begin{array}{l}\text { Setiap } \\
\text { dibutuhkan }\end{array}$ \\
\hline & & $\begin{array}{l}\text { Memberikan bimbingan } \\
\text { penggunaan } \\
\text { perpustakaan }\end{array}$ & Setiap hari \\
\hline
\end{tabular}




\begin{tabular}{|c|c|c|c|}
\hline & & $\begin{array}{l}\text { Memberikan } \\
\text { penghargaan kepada } \\
\text { peminjam terbanyak }\end{array}$ & $\begin{array}{l}\text { Satu tahun } \\
\text { sekali }\end{array}$ \\
\hline & & $\begin{array}{l}\text { Memberikan } \\
\text { penghargaan kepada } \\
\text { pecinta buku terajin }\end{array}$ & $\begin{array}{l}\text { Satu tahun } \\
\text { sekali }\end{array}$ \\
\hline & & $\begin{array}{l}\text { Mengadakan lomba } \\
\text { menulis puisi dan resensi }\end{array}$ & $\begin{array}{l}\text { Satu } \\
\text { semester }\end{array}$ \\
\hline \multicolumn{4}{|c|}{ Pengolahan Data } \\
\hline $\begin{array}{l}\text { Laporan } \\
\text { Perpustakaan }\end{array}$ & $\begin{array}{l}\text { Membuat laporan kegiatan } \\
\text { pengelolaan perpustakaan }\end{array}$ & $\begin{array}{l}\text { Mengevaluasi kinerja } \\
\text { perpustakaan }\end{array}$ & $\begin{array}{l}\text { Enam bulan } \\
\text { sekali }\end{array}$ \\
\hline $\begin{array}{l}\text { Statistik } \\
\text { perpustakaan }\end{array}$ & $\begin{array}{l}\text { Membuat statistik jumlah } \\
\text { pengunjung, peminjaman dan } \\
\text { kondisi koleksi yang dimiliki }\end{array}$ & $\begin{array}{l}\text { Mengetahui } \\
\text { perkembangan minat } \\
\text { siswa dan guru terhadap } \\
\text { keberadaan perpustakaan }\end{array}$ & $\begin{array}{l}\text { Satu tahun } \\
\text { sekali }\end{array}$ \\
\hline \multicolumn{4}{|l|}{ Kegiatan Siswa } \\
\hline Pembiasaan & $\begin{array}{l}\text { Memberikan tugas mata pelajaran } \\
\text { bahasa Indonesia yang bersumber } \\
\text { dari perpustakaan }\end{array}$ & $\begin{array}{lr}\text { Menumbuhkan } & \text { minat } \\
\text { berkunjung } & \text { dan } \\
\text { membaca } & \text { di } \\
\text { perpustakaan } & \\
\end{array}$ & $\begin{array}{l}\text { Sesuai } \\
\text { jadwal } \\
\text { pembiasaan }\end{array}$ \\
\hline $\begin{array}{l}\text { Iuaran } \\
\text { langganan } \\
\text { perpustakaan }\end{array}$ & $\begin{array}{l}\text { Siswa memberi iuran untuk } \\
\text { berlangganan majalah siswa satu } \\
\text { bulan Rp. } 1000\end{array}$ & $\begin{array}{l}\text { Menumbuhkan } \\
\text { kepedulian siswa } \\
\text { terhadap perpustakaan } \\
\text { dan menumbuhkan } \\
\text { minat baca pada siswa, } \\
\text { serta menambah koleksi } \\
\text { bacaan di perpustakaan } \\
\text { dan informasi selalu up } \\
\text { to date }\end{array}$ & $\begin{array}{l}\text { Satu bulan } \\
\text { sekali }\end{array}$ \\
\hline \multicolumn{4}{|l|}{ Promosi } \\
\hline $\begin{array}{l}\text { Orientasi } \\
\text { perpustakaan }\end{array}$ & $\begin{array}{l}\text { Mengenalkan perpustakaan } \\
\text { terutama kepada siswa baru }\end{array}$ & $\begin{array}{l}\text { Menarik minat siswa } \\
\text { terhadap perpustakaan }\end{array}$ & $\begin{array}{l}\text { Awal tahun } \\
\text { ajaran baru }\end{array}$ \\
\hline $\begin{array}{l}\text { Program } \\
\text { Perpustakaan } \\
\text { Mini MGMP }\end{array}$ & 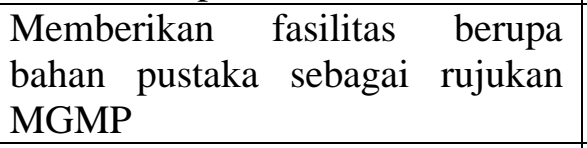 & $\begin{array}{l}\text { Meningkatkan minat } \\
\text { baca guru }\end{array}$ & $\begin{array}{l}\text { Sesuai } \\
\text { kebijakan } \\
\text { sekolah }\end{array}$ \\
\hline User education & $\begin{array}{l}\text { Memberikan bimbingan } \\
\text { penggunaan perpustakaan }\end{array}$ & $\begin{array}{l}\text { Mengenalkan } \\
\text { perpustakaan kepada } \\
\text { pemustaka }\end{array}$ & Setiap hari \\
\hline $\begin{array}{l}\text { Memberikan } \\
\text { penghargaan }\end{array}$ & $\begin{array}{l}\text { Memberikan penghargaan kepada } \\
\text { pengunjung terajin, memberikan } \\
\text { penghargaan kepada peminjam } \\
\text { terbanyak, dan memberikan } \\
\text { penghargaan kepada pecinta buku } \\
\text { terajin }\end{array}$ & $\begin{array}{l}\text { Merangsang pemustaka } \\
\text { untuk sering datang ke } \\
\text { perpustakaan }\end{array}$ & $\begin{array}{l}\text { Setiap akhir } \\
\text { tahun ajaran }\end{array}$ \\
\hline $\begin{array}{l}\text { Mengadakan } \\
\text { lomba-lomba }\end{array}$ & $\begin{array}{l}\text { Mengadakan lomba menulis puisi } \\
\text { dan resensi }\end{array}$ & $\begin{array}{l}\text { Meningkatkan } \\
\text { baca }\end{array}$ & $\begin{array}{l}\text { Akhir } \\
\text { semester }\end{array}$ \\
\hline $\begin{array}{l}\text { Sosialisasi } \\
\text { program rekor } \\
\text { baca }\end{array}$ & Menerbitkan iklan dan leaflet & $\begin{array}{l}\text { Meningkatkan } \\
\text { baca }\end{array}$ & \\
\hline
\end{tabular}




\begin{tabular}{|l|l|l|c|}
\hline STOCK & $\begin{array}{l}\text { Mengecek koleksi dan harta yang } \\
\text { dimiliki dan penyiangan terhadap } \\
\text { KoPNAME }\end{array}$ & $\begin{array}{l}\text { Mengetahui kondisi } \\
\text { koleksi maupun semua } \\
\text { harta kekayaan yang } \\
\text { dimiliki perpustakaan }\end{array}$ & Juni-Juli \\
\hline
\end{tabular}

\section{Pelaksanaan Program Kerja}

Pelaksanaan program kerja diatas adalah dalam rangka untuk meningkatkan kualitas layanan pemustaka dan menarik minat baca siswa. Dengan pelaksanaan program kerja yang baik, secara tidak langsung akan meningkatkan kualitas layanan dan minat baca pemustaka (Yudiarti, 2019).

Selain pelaksanaan program kerja tersebut, perpustakaan SMPN 3 Salatiga juga mengadakan kerjasama perpustakaan yang dilakukan dengan intern sekolah maupun ekstern sekolah. Kerjasama tersebut dilaksanakan dengan maksud untuk lebih meningkatkan kualitas layanan perpustakaan baik untuk menambah koleksi jumlah buku, pembinaan kualitas layanan, kerjasama pinjam koleksi dengan perpustakaan lain maupun kerjasama diklat atau magang. Kerjasama perpustakaan tersebut antara lain :

1. Kerjasama dengan Kepala Sekolah

Kerjasama dengan kepala sekolah diwujudkan dengan kerjasama dalam pengelolaan perpustakaan. Kepala sekolah secara berkala melakukan rapat koordinasi bersama staff perpustakaan untuk kemajuan perpustakaan.

2. Kerjasama dengan dewan guru

Kerjasama dengan dewan guru diwujudkan dengan disediakannya Perpustakaan Mini MGMP. Dalam perpustakaan ini disediakan buku-buku yang berkaitan dengan metode dan model pembelajaran, hasil penelitian (PTK) guru, dan jurnal ilmiah mengenai pendidikan.
3. Kerjasama dengan orang tua siwa dan Komite Sekolah

Kerjasama dengan orang tua dilakukan dengan cara melakukan kegiatan sumbang buku kepada perpustakaan setelah anak kelas IX lulus.

4. Kerjasama dengan alumnus

Kerjasama dengan alumnus diwujudkan dengan kegiatan "Tali Asih" berupa penyerahan kenang-kenangan bahan pustaka dari para alumnus kepada perpustakaan Adyama Pustaka.

5. Kerjasama dengan siswa

Kerjasama dengan siswa dilakukan dengan cara melakukan kerjasama melanggan majalah bersama.

6. Kerjasama dengan perpustakaan umum lain

Perpustakaan Adyama Pustaka menjalin kerjasama dengan perpustakaan umum Perpusda Kota Salatiga berupa kerjasama pinjam koleksi.

7. Kerjasama dengan perpustakaan Perguruan Tinggi

Adyama Pustaka telah melaksanakan kerjasama dengan dua perguruan tinggi besar di Salatiga yaitu IAIN Walisongo berupa kerjasama keanggotaan dan Universitas Kristen Satya Wacana (UKSW) berupa pembinaan. Adyama Pustaka juga bekerjasama dengan Universitas Terbuka UPBJJ Semarang berupa pembinaan peserta magang Fakultas Fisip Jurusan Ilmu Perpustakaan.

8. Kerjasama dengan perpustakaan sekolah lain

Perpustakaan Adyama Pustaka bekerjasama dengan perpustakaan SMPN 1 Salatiga dalam bidang pinjam koleksi dan sharing pengelolaan perpustakaan. 
9. Kerjasama dengan Dinas Pendidikan Setempat

Kerjasama juga dilaksanakan dengan Disdikpora Kota Salatiga berupa pembinaan dan bantuan koleksi.

10. Kerjasama dengan Yayasan

Kerjasama dengan yayasan dilakukan bersama Yayasan Arsari

Djoyohadikusumo berupa pemberian koleksi buku.

Pelaksanaan program kerja perpustakaan SMPN 3 Salatiga telah terlaksana dengan baik sesuai dengan program dan kebutuhan. Selain itu untuk menambah kualitas layanan perpustakaan SMPN 3 Salatiga bekerja sama dengan instansi lain. Pelaksanaan program kerja dan kerjasama ini dilaksanakan dalam rangka untuk meningkatkan kualitas layanan dan minat baca siswa dengan baik.

\section{Evaluasi Program Kerja}

Evaluasi pelaksanaan tiap program kerja perpustakaan SMP N 3 Salatiga, yaitu :

a. Pelaksanaan program kerja pengadaaan Pelaksanaan program kerja pengadaan terdiri dari persiapan, seleksi bahan pustaka, pemesanan/pembelian buku, inventarisasi, pemesanan langganan terbitan berseri, dan pengadaaan sarana dan prasarana fisik, telah terlaksana dengan baik sesuai dengan program dan kebutuhan, walaupun masih ada program tertentu yang belum terlaksana yaitu program pengadaan koran dinding, disebabkan karena terkendala tempat pemasangan.

b. Pengolahan bahan pustaka, terdiri dari katalogisasi dan klasifikasi, input data dan entry data buku baru, pelabelan dan display buku telah terlaksana dengan baik sesuai dengan program dan kebutuhan.

c. Program layanan, terdiri dari layanan sirkulasi, layanan referensi, layanan bimbingan membaca, layanan keanggotaan, layanan penyediaan buku pelajaran/paket, layanan orientasi yang diberikan kepada pembaca, layanan bimbingan cara mereview buku, layanan teknik penelusuran informasi, layanan pendidikan pemakai, layanan bimbingan menulis karya ilmiah, layanan ruang baca, layanan akses internet, dan layanan promosi telah terlaksana dengan baik sesuai dengan program dan kebutuhan.

d. Program pengolahan data, terdiri dari laporan perpustakaan dan statistik perpustakaan telah terlaksana dengan baik sesuai dengan program dan kebutuhan.

e. Program kegiatan siswa, terdiri dari program pembiasaan, dan iuran langganan perpustakaan telah terlaksana dengan baik sesuai dengan program dan kebutuhan.

f. Program promosi, terdiri dari orientasi perpustakaan, program perpustakaan mini MGMP, user education, memberikan penghargaan, dan mengadakan lomba-lomba telah terlaksana dengan baik sesuai dengan program dan kebutuhan.

g. Stock opname, terdiri dari pengecekan koleksi dan harta yang dimiliki serta penyiangan terhadap koleksi yang out of date telah terlaksana dengan baik sesuai dengan program dan kebutuhan.

Program kerja perpustakaan SMPN 3 Salatiga, sudah sesuai dengan perencanaan program perpustakaan yang terdiri dari tujuan, kebijakan, strategi, dan program. Semua program kerja yang telah 
dirumuskan sudah menggambarkan aspek tujuan, kebijakan, strategi, dan program yang akan dijalankan untuk mencapai hasil yang dikehendaki.

Sedangkan pelaksanaan program kerja perpustakaan SMPN 3 Salatiga semuanya telah berjalan dengan baik dan sesuai dengan kebutuhan perpustakaan. Juga ditambah upaya perpustakaan SMPN 3 Salatiga untuk menjalin kerjasama dengan pihak intern dan ekstern. Semua itu bertujuan untuk meningkatkan kualitas layanan dan minat baca siswa.

\section{Kualitas Layanan Perpustakaan di SMP N 3 Salatiga}

Kualitas layanan perpustakaan merupakan bentuk pelayanan yang diberikan kepada pengguna sesuai dengan standar layanan yang telah dilakukan sebagai pedoman dalam pemberian layanan. Standar layanan adalah ukuran yang telah ditentukan sebagai suatu pembakuan layanan yang baik. Kualitas layanan adalah tingkat keunggulan yang diharapkan dan pengendalian atas tingkat keunggulan tersebut untuk memenuhi keinginan pelanggan (Tjiptono, 2008:59).

Penilaian kegiatan layanan perpustakaan adalah segala usaha, tindakan atau proses untuk menentukan kualitas kemajuan kegiatan yang berkaitan dengan pelaksanaan program layanan perpustakaan dengan mengacu kepada kriteria atau patokan-patokan tertentu sesuai dengan program yang dilaksanakan. Kriteria atau patokan yang dipakai untuk menilai keberhasilan pelaksanaan program layanan perpustakaan adalah mengacu pada terpenuhi atau tidak terpenuhinya kebutuan pemustaka dan stake holder untuk memperoleh kebutuhan informasi dari perpustakaan. Penilaian diperlukan untuk memperoleh umpan balik terhadap keefektifan layanan perpustakaan yang dilaksanakan. Dengan penilaian dapat diketahui sejauh mana keberhasilan layanan perpustakaan dan dapat ditetapkan langkah-langkah tindak lanjut untuk memperbaiki dan mengembangkan program layanan selanjutnya. Bidangbidang yang dapat digunakan untuk pengevaluasian layanan perpustakaan, yaitu : anggaran, koleksi, gedung dan fasilitas, keterjangkauan dan ketersediaan, pemeliharaan dan pelestarian, keterpakaian koleksi serta mutu layanan (Cahyono, 2017).

Secara umum layanan pengguna didefinisikan sebagai aktivitas perpustakaan dalam memberikan jasa layanan kepada pengguna perpustakaan, khususnya kepada anggota perpustakaannya. Jenis layanan yang dilaksanakan oleh perpustakaan SMPN 3 Salatiga meliputi layanan sebagai berikut :

a. Layanan orientasi yang diberikan kepada pembaca

b. Layanan bimbingan cara mereview buku

c. Layanan teknik penelusuran informasi

d. Layanan pendidikan pemakai

e. Layanan bimbingan menulis karya ilmiah

f. Layanan ruang baca

g. Layanan sirkulasi

h. Layanan akses internet

i. Layanan promosi

Berdasarkan hasil pelaksanaan program kerja layanan perpustakaan di SMPN 3 Salatiga, maka penulis mengambil kesimpulan antara lain sebagai berikut:

a. Pelaksanaan program kerja layanan perpustakaan di SMPN 3 Salatiga telah 
berjalan dengan baik dan sesuai dengan kebutuhan pemustaka. Hal ini dibuktikan dengan berbagai macam jenis layanan yang diberikan kepada pemustaka dalam rangka meningkatkan kualitas layanan dan minat baca siswa.

b. Selain pelaksanaan program kerja tersebut, perpustakaan SMPN 3 Salatiga juga mengadakan kerjasama perpustakaan yang dilakukan dengan intern sekolah maupun ekstern sekolah. Kerjasama perpustakaan tersebut antara lain dengan kepala sekolah, dewan guru, orang tua siswa dan komite sekolah, alumnus, siswa, perpustakaan umum (perpustakaan daerah), perpustakaan perguruan tinggi, perpustakaan sekolah lain, dinas pendidikan setempat dan dengan yayasan.

c. Adanya penelitian dari kepala perpustakaan berupa kajian kepuasan pemustaka terhadap layanan perpustakaan Adyama Pustaka SMPN 3 Salatiga, yang menunjukkan bahwa responden guru dan siswa merasa puas terhadap kinerja pelayanan, respon terhadap keinginan, kompetensi petugas, pengaksesan yang mudah, kualitas koleksi, ketersediaan alat temu kembali, dan waktu layanan. (terlampir)

Dengan kualitas layanan yang baik, secara tidak langsung akan meningkatkan minat baca siswa. Peningkatan minat baca siswa di SMPN 3 Salatiga dapat dilihat dari hasil rekap data pengunjung dan data peminjaman.

\section{Meningkatkan Minat Baca Siswa SMP N 3 Salatiga}

Hasil penelitian dengan melakukan wawancara kepada pimpinan perpustakaan dan staff di SMPN 3
Salatiga menunjukkan bahwa salah satu program utama yang harus dijalankan untuk meningkatkan minat baca siswa adalah dengan menganggap dan memposisikan perpustakaan sangat penting kedudukannya bagi sekolah dan siswa. Hal ini didasarkan pada satu pengalaman dari pimpinan perpustakaan di sekolah tersebut bahwa salah satu faktor rendahnya minat baca siswa dapat dipengaruhi oleh kurangnya peran perpustakaan dalam menyediakan informasi yang akurat dan sesuai dengan kebutuhan siswa dan sekolah.

UU No. 43 tahun 2007 tentang perpustakaan menyatakan bahwa keberadaan perpustakaan tidak dapat dipisahkan dari peradaban dan budaya umat manusia. Tinggi rendahnya peradaban dan budaya suatu bangsa dapat dilihat dari kondisi perpustakaan yang dimiliki.

Mengacu atas dasar UU tersebut, pimpinan perpustakaan SMPN 3 Salatiga menyatakan bahwa seharusnya perpustakaan dapat menjadi tempat belajar untuk siswa dan guru di sekolah. Pelaksanaan peningkatan minat baca yang telah dilaksanakan oleh perpustakaan SMPN 3 Salatiga adalah sebagai berikut:

1) Sejak calon siswa menjadi siswa dimulai dari tahun ajaran baru, seluruh siswa telah dikenalkan program perpustakaan sekolah.

Upaya ini cukup efektif, dimulai dari sosialisasi sejak dini ketika anak-anak mengikuti Masa Orientasi Siswa (MOS), berupa sosialisasi perpustakaan sekolah bahwa membaca di perpustakaan merupakan bagian dari suatu aktifitas membaca baik bagi guru maupun siswa. Hal tersebut bisa dilihat dengan adanya data pengunjung di 
perpustakaan dari tahun ke tahun makin meningkat.

2) Mengelompokkan sesuai dengan jenjang dan kemampuan siswa dalam membaca.

Setelah siswa sedari awal senang dengan aktifitas membaca, maka kemampuan siswa akan dikelompokkan sesuai dengan kapasitas masing-masing siswa. Pengelompokan ini penting mengingat tidak semua siswa berkemampuan sama. Sebagai upaya untuk terus meningkatkan minat baca siswa, maka siswa yang berperstasi dan berkemampuan akan diikutkan lomba dan sekolah memberikan fasilitas dalam kegiatan lomba yang diikuti siswa.

3) Menjadikan program membaca di perpustakaan merupakan program ekstrakurikuler

Sekolah selama ini telah menjadikan program perpustakaan sebagai sebuah ekstrakurikuler yang dapat diikuti oleh siswa. Kegiatan ini telah berlangsung lama, sehingga dalam perjalanannya pimpinan dan staff perpustakaan hanya menyempurnakan dan mengikuti perkembangan zaman.

4) Menjadikan perpustakaan berbasis teknologi

Upaya yang dilakukan perpustakaan adalah dengan membuat aplikasi berbasis teknologi untuk memudahkan pengelolaan perpustakaan. Hal ini juga mempermudah siswa mencari berbagai buku bacaan dan dapat diakses dimana saja siswa berada.

5) Bekerjasama dengan guru Bahasa Indonesia dalam program literasi sekolah.

Upaya yang dilakukan perpustakaan untuk meningkatkan minat baca siswa salah satunya adalah dengan program literasi yang bekerjasama dengan guru Bahasa Indonesia.

6) Menjadikan perpustakaan sebagai bahan ajar bagi guru.

Sekolah membuat kebijakan bahwa perpustakaan merupakan sumber belajar untuk guru dalam upaya meningkatkan kemampuan mengajar dan mencari sumber belajar. Guru tidak semata-mata mengandalkan buku-buku yang sudah disediakan dari sekolah atau kelompok kerja guru, namun juga bersumber dari perpustakaan.

7) Pemberian kualitas layanan yang baik kepada pemustaka dengan penyediaan berbagai macam layanan di perpustakaan SMPN 3 Salatiga, yang salah satunya adalah layanan promosi yang berisi : a) Mengadakan program SMUCA (Sepuluh Menit Membaca). b) Membuat leaflet profil perpustakaan. c) Mengadakan pameran buku sederhana. d) Menerbitkan buletin secara berkala. e) Mengumumkan daftar buku baru. f) Memberikan fasilitas berupa bahan pustaka sebagai rujukan kegiatan MGMP g) Memberikan bimbingan penggunaan perpustakaan. $h$ ) Memberikan penghargaan kepada peminjam terbanyak i) Memberikan penghargaan kepada pecinta buku terajin j) Mengadakan lomba menulis puisi dan resensi k) Mengadakan kegiatan Rekor Baca.

8) Layanan kegiatan siswa yang terdiri dari: 1) menggiatkan program rekor baca dengan tujuan mengaktifkan siswa lebih banyak membaca berbagai macam judul buku, 2) mengelola sudut baca dengan tujuan melayani teman sebaya yang mau membaca di sudut baca dengan cara membentuk tim dari siswa 
untuk membantu petugas mengelola program perpustakaan.

9) Penataan perpustakaan yang baik dan kebersihan lingkungan serta ruangan perpustakaan merupakan faktor yang ikut mempengaruhi minat baca siswa ke perpustakaan.

Ibu Retno Setyowati selaku kepala perpustakaan, mengadakan kajian ilmiah yang berjudul "Rekor Baca Sebagai Alternatif Meningkatkan Minat Baca Peserta Didik SMPN 3 Salatiga”. Kesimpulan dari kajian ilmiah tersebut adalah terjadi peningkatan kunjungan perpustakaan dan peminjaman setiap tahunnya. Selain itu juga kepala perpustakaan mengadakan kajian kepuasan pemustaka terhadap layanan perpustakaan Adyama Pustaka SMPN 3 Salatiga, yang menunjukkan bahwa responden guru dan siswa merasa puas terhadap kinerja pelayanan, respon terhadap keinginan, kompetensi petugas, pengaksesan yang mudah, kualitas koleksi, ketersediaan alat temu kembali, dan waktu layanan.

Hasil penelitian ini senada dengan penelitian yang dilakukan oleh Toha (2015) dengan judul penelitiannya "Upaya pengelola perpustakaan dalam meningkatkan minat baca siswa pada mata pelajaran Pendidikan Agama Islam”.

Hasil penelitian yang diperoleh oleh peneliti dilapangan, penulis menyimpulkan bahwa, (1) Upaya Pengelola Perpustakaan dari Segi Pemberian Pinjaman buku dalam Meningkatkan Minat Baca Siswa Pada Mata Pelajaran Pendidikan Agama Islam ialah: mempermudah dalam prosedur peminjaman buku, mensosialisasikan prosedur peminjaman, memberikan pelayanan pinjaman dengan ramah dan komunikatif, peningkatan SDM di perpustakaan, pemberian rewerd bagi siswa yang paling banyak meminjam buku. (2) Upaya Pengelola Perpustakaan dari Segi Pengelolaan Ruang Baca dalam Meningkatkan Minat Baca Siswa Pada Mata Pelajaran Pendidikan Agama Islam . Meningkatan minat baca siswa ialah: tata ruang yang menarik dan nyaman, memperluas ruang baca, lingkungan yang tenang dengan vasilitas vasilitas yang memadai. (3) Upaya Pengelola Perpustakaan dari Segi Koleksi Buku dalam Meningkatkan Minat Baca Siswa Pada Mata Pelajaran Pendidikan Agama Islam ialah: meningkatkan ragam koleksi buku perpustakaan, melibatkan guru bidang studi dalam pemilihan koleksi buku perpustakaan, meningkatkan anggaran untuk koleksi buku baru,penambahan koleksi buku dengan pemberian dari setiap siswa yang akan lulus. (4) Upaya pengelola perpustakaan sekolah melalui interaksi dengan pihak sekolah dalam meningkatkan minat baca siswa pada mata pelajaran pendidikan agama Islam ialah: menjalin kerjasama dengan kepala madrasah, menjalin kerjasama dengan guru, menjalin kerjasama pihak sekolah dan perpustakaan dengan elemen masyarakat khususnya kolektor buku, menjalin kerjasama dengan instansi pemerintah dan swasta.

\section{SIMPULAN}

Manajemen perpustakaan dalam meningkatkan pelayanan dan minat baca peserta didik di SMP N 3 Salatiga terdiri dari kegiatan perencanaan, pelaksanaan, dan evaluasi. Perencanaan program kerja perpustakaan meliputi perencanaan pengadaan, perencanaan pengolahan bahan pustaka, perencanaan layanan, perencanaan program pengolahan data, perencanaan program kegiatan siswa, 
perencanaan program promosi, dan perencanaan stock opname. Pelaksanaan program kerja perpustakaan meliputi pelaksanaan pengadaan, pelaksanaan pengolahan bahan pustaka, pelaksanaan layanan, pelaksanaan program pengolahan data, pelaksanaan program kegiatan siswa, pelaksanaan program promosi, dan pelaksanaan stock opname. Kegiatan selanjutnya adalah evaluasi. Evaluasi terhadap perencanaan dan pelaksanaan program kerja perpustakaan sebagai pijakan untuk menentukan kebijakankebijakan manajemen perpustakaan pada tahun-tahun berikutnya secara berkesinambungan.

\section{DAFTAR PUSTAKA}

Bafadal, I. (2011). Pengelolaan Perpustakaan Sekolah. PT Bumi Aksara.

Cahyono, T. Y. (2017). Evaluasi Layanan Perpustakaan. Perpustakaan UM. http://lib.um.ac.id/index.php/2017/07/ 23/evaluasi-layanan-perpustakaan/

Hermawan, A. H., Hidayat, W., \& Fajari, I. (2020). Manajemen Perpustakaan dalam Meningkatkan Minat Baca Peserta Didik. ISEMA: Jurnal Islamic Education Manajemen, 5(1), 113126.

https://doi.org/10.15575/isema.v5i1.6 151

Ibrahim, A. (2014). Konsep Dasar Manajemen Perpustakaan dalam Mewujudkan Mutu Layanan Prima dengan Sistem Temu Kembali Informasi Berbasil Digital. KHIZANAH AL-HIKMAH, 2(2), 129138.

Luthfiyah, F. (2015). Manajemen Perpustakaan dalam Meningkatkan Layanan Perpustakaan. Jurnal ElIdare, 1(2), 189-202.

Prastowo, A. (2013). Panduan Kreatif Membuat Bahan Ajar Inovatif. Diva
Press.

Rokan, M. R. (2017). Manajemen Perpustakaan Sekolah. Jurnal Iqra', 11(01), 88-100.

Saleh, \& Komalasari. (2010). Manajemen Perpustakaan. Universitas Terbuka.

Sudarsana, \& Bastiono. (2010). Pembinaan Minat Baca. Universitas Terbuka.

Sudjana, N., \& Ibrahim. (2012). Penelitian dan Penilaian Pendidikan. Sinar Baru Algensindo.

Suhaemin, \& Arikunto, S. (2013). Manajemen Perpustakaan Di Madrasah Aliyah Negeri Yogyakarta. Jurnal Akuntabilitas Manajemen Pendidikan, 1(2), 252-268. https://doi.org/10.21831/amp.v1i2.23 98

Sumiati, O. (2011). Pengelolaan Perpustakaan Sekolah. Universitas Terbuka.

Tjiptono, F. (2008). Strategi Pemasaran. Andi.

Toha, M. (2015). Upaya Pengelola Perpustakaan dalam Meningkatkan Minat Baca Siswa pada Mata Pelajaran Pendidikan Agama Islam (Studi Multi Situs di MTs Negeri Tulungagung dan MTs As-S yafi'iyah Gondang). IAIN Tulungagung.

Yudiarti, E. F. (2019). Manajemen Perpustakaan dalam Upaya Meningkatkan Minat Baca Peserta Didik di MAN 01 Kota Bengkulu. Al Maktabah, 4(1), 44-55. 